\title{
Skeleton growth and density pattern of the temperate, zooxanthellate scleractinian Cladocora caespitosa from the Ligurian Sea (NW Mediterranean)
}

\author{
Andrea Peirano ${ }^{1, *}$, Carla Morri $^{2}$, C. Nike Bianchi ${ }^{1}$ \\ ${ }^{1}$ Marine Environment Research Centre, ENEA Santa Teresa, PO Box 316, I-19100 La Spezia, Italy \\ ${ }^{2}$ DipTeRis, Dipartimento per lo studio del Territorio e delle sue Risorse (Zoologia), Via Balbi 5, I-16126 Genova, Italy
}

\begin{abstract}
X-radiographs of corallites of the zooxanthellate coral Cladocora caespitosa (L.), collected in the Ligurian Sea between 3 and $27 \mathrm{~m}$ depth, were examined. C. caespitosa deposits 2 bands $\mathrm{yr}^{-1}$; the high density band is deposited during winter (November to March) while the low density band is deposited in summer. Average growth rates ranged from $1.36 \pm 0.58$ to $4.42 \pm 1.61 \mathrm{~mm} \mathrm{Yr}^{-1}$ No differences in the timing of band deposition were found between shallow and deep colonies. A comparison of the band pattern with monthly temperature-irradiance measurements from the Ligurian Sea, and with literature data on the photosynthetic efficiency of zooxanthellae, led us to hypothesise a mechanism of growth with a low dependency on autotrophy.
\end{abstract}

KEY WORDS: Coral · Cladocora caespitosa $\cdot$ Growth $\cdot$ Mediterranean Sea

\section{INTRODUCTION}

Many papers have been published on coral growth since X-radiography was first used to demonstrate the annual banding pattern (Knutson et al. 1972, Buddemeier et al. 1974). Despite some problems in the interpretation of density band patterns related to the 3-dimensional development of corallites (Barnes \& Lough 1989, Lough \& Barnes 1990, Barnes \& Taylor 1993, Le Tissier et al. 1994) and a few exceptions (Charuchinda \& Chansang 1985, Brown et al. 1986), the deposition of 1 high density (HD) and 1 low density (LD) band per year has been widely accepted. Coral banding has been related to both cyclic variation of environmental parameters (Knutson et al. 1972, Buddemeier et al. 1974, Lough \& Barnes 1997) and anthropogenic disturbance (Hudson et al. 1994). Both influence the packing of skeletal elements (Oliver et al. 1983, Barnes \& Devereux 1988, Barnes \& Lough 1993).

\footnotetext{
•E-mail: peirano@estosf.santateresa.enea.it
}

Comparing banding patterns of hermatypic corals, Highsmith (1979) proposed a model whereby the banding pattern changes with latitude. He hypothesised that in 'high latitude' (temperate) corals, HD bands form during periods of low temperature and low light intensity, whereas LD bands form during periods of high temperature and high light intensity. This assumption was confirmed by observations on Porites species living in shallow water in the Red Sea (Klein \& Loya 1991, Klein et al. 1992). In deep samples of the same genus, however, Klein et al. (1993) highlighted a shift to an opposite, depth-related deposition pattern and outlined the importance of investigating the nature and timing of band deposition in extreme conditions.

Cladocora caespitosa (L.) is the only colonial and zooxanthellate coral native to the Mediterranean (Zibrowius 1980) and belongs to the Faviidae, a family among the most important reef builders in tropical areas. It lives between the surface and $50 \mathrm{~m}$ depth and has Recent and Pleistocene records (Bernasconi et al. 1997, Aguirre \& Jiménez 1998). Where abundant, it 
forms 'beds' of globose to hemispherical colonies or banks up to more than $1 \mathrm{~m}$ high and covering several square metres (Laborel 1961, Kühlmann et al. 1991, Schiller 1993a, Morri et al. 1994, Kühlmann 1996). The colonies of $C$. caespitosa are phaceloid, i.e. the corallites develop vertically, each having its own walls independent of the others. The occurrence of an altermating dense and less dense banding on $X$-radiographs, as in the most studied tropical relatives, has been demonstrated only recently (Peirano et al. 1998).

In the present paper, we report for the first time on the corallite structure and sclerochronological data of Cladocora caespitosa from the Ligurian Sea (NW Mediterranean). The timing of HD and LD band deposition was reconstructed by comparing samples from different periods of the year, and then related to seasonal change in water temperature and irradiation. The annual growth was calculated from colonies at different sites and depths.

\section{METHODS}

In 1994, 24 colonies of Cladocora caespitosa were collected at 3 sites in the La Spezia region, Italy (Fig. 1): Punta Bianca (March and November, $3 \mathrm{~m}$ depth), Capo di Montenero (July, $10 \mathrm{~m}$ ) and Cala Grande (July, $20 \mathrm{~m}$ ). One further sample was taken at Bonassola (March, $27 \mathrm{~m}$ depth) from a large bank (Morri et al. 1994).

In the laboratory, the colonies were measured and as many long, rectilinear, isoplanar (i.e. developed in 1 plane) and unbored corallites as possible were carefully isolated. Cleared of living or subfossil epibionts,

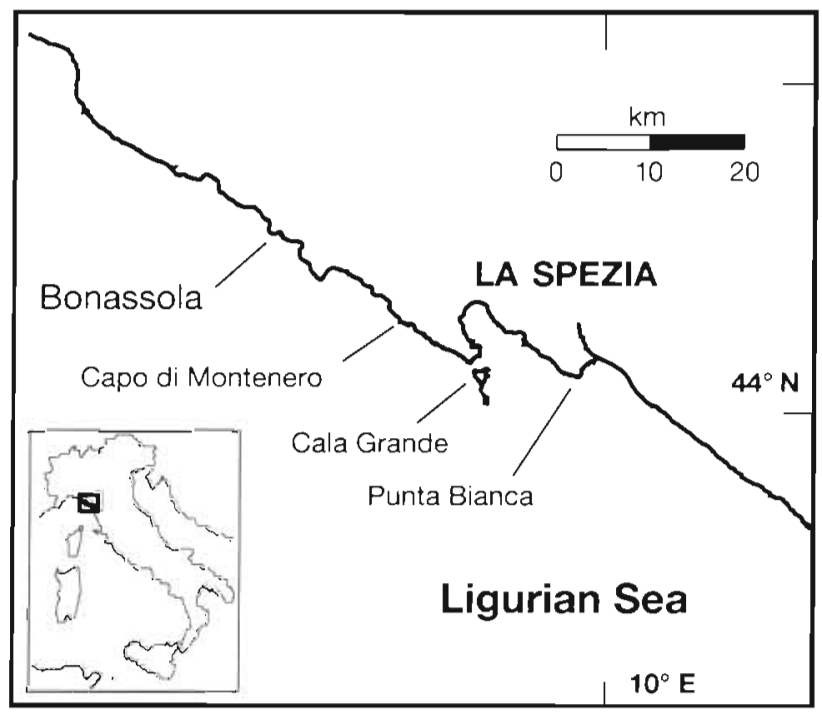

Fig. 1. Coastal region of La Spezia, Italy, and sampling sites the corallites were immersed in a 1:1 peroxide solution to remove organic remains and dried at $70^{\circ} \mathrm{C}$. Skeletal features of the corallite were observed by stereomicroscopy and scanning electron microscope on sagittal sections obtained with a grinding machine.

To measure growth rates and timing of band deposition, the corallites were $\mathrm{X}$-rayed with a medical unit Senograph 500t-CGR mammography machine (exposure conditions of $31 \mathrm{kV}, 25 \mathrm{~mA}$ at a distance of $30 \mathrm{~cm}$ ). Contact prints obtained from X-ray films on high contrast paper were scanned and the computer images of corallites were analysed with the public domain NIH-Image programme for Macintosh. The software gave a value of optical density (OD) to each pixel of the scanned images, ranging from 0 (white) to 255 (black) (Fig. 2). Image analysis, performed along the corallite axis, produced a plot of computed mean optical density that allowed the HD density peaks to be recognised and the distances between them to be measured (Fig. 2). Annual mean growth rates were computed for each colony and related to colony morphology. Colony morphology was described as the degree of sphericity using the Is-index of Riegl (1995): Is = maximal height/ maximal diameter. Data were analysed using the SYSTAT (SPSS Inc., Chicago) statistical package for PC

Timing of band deposition was compared with monthly water temperature of the Ligurian Sea (Picco 1990 ) and monthly photosynthetically active radiation (PAR) at 3, 10, 20 and $27 \mathrm{~m}$ depth. PAR irradiances at the sea surface were calculated with the formula: $E(\mathrm{PAR})=0.43 E(\mathrm{G})($ Innamorati 1990), where $E(\mathrm{G})$ was the monthly irradiance of global terrestrial irradiation measured with a pyranometer for the years 1958 to 1977 (Osservatorio Meteorologico di Genova 1985). Values in watts per square metre were multiplied by 4.6 to convert into micro-Einsteins per second per square metre (McCree 1972). To compute PAR monthly irradiance at the 4 depths, we used the 2 equations:

$$
K C=1.7 S d^{-1} \text { and } I_{z}=\mathrm{e}^{-K c \cdot z}
$$

where $K c$ is the light extinction coefficient, $S d$ is the water transparency measured by Secchi-disk, and $I_{z}$ is the light intensity (as \% of surface irradiance) at each depth $z$ (in metres). Secchi-disk water transparency for the studied zone has a mean value of $11.6 \mathrm{~m}$ (Della Croce et al. 1992).

\section{RESULTS}

\section{Corallite structure}

Ground, sagittal sections of corallites showed the typical scleractinian architecture described by $\mathrm{Zi}$ browius (1980) and Veron (1993). Primary septa form 


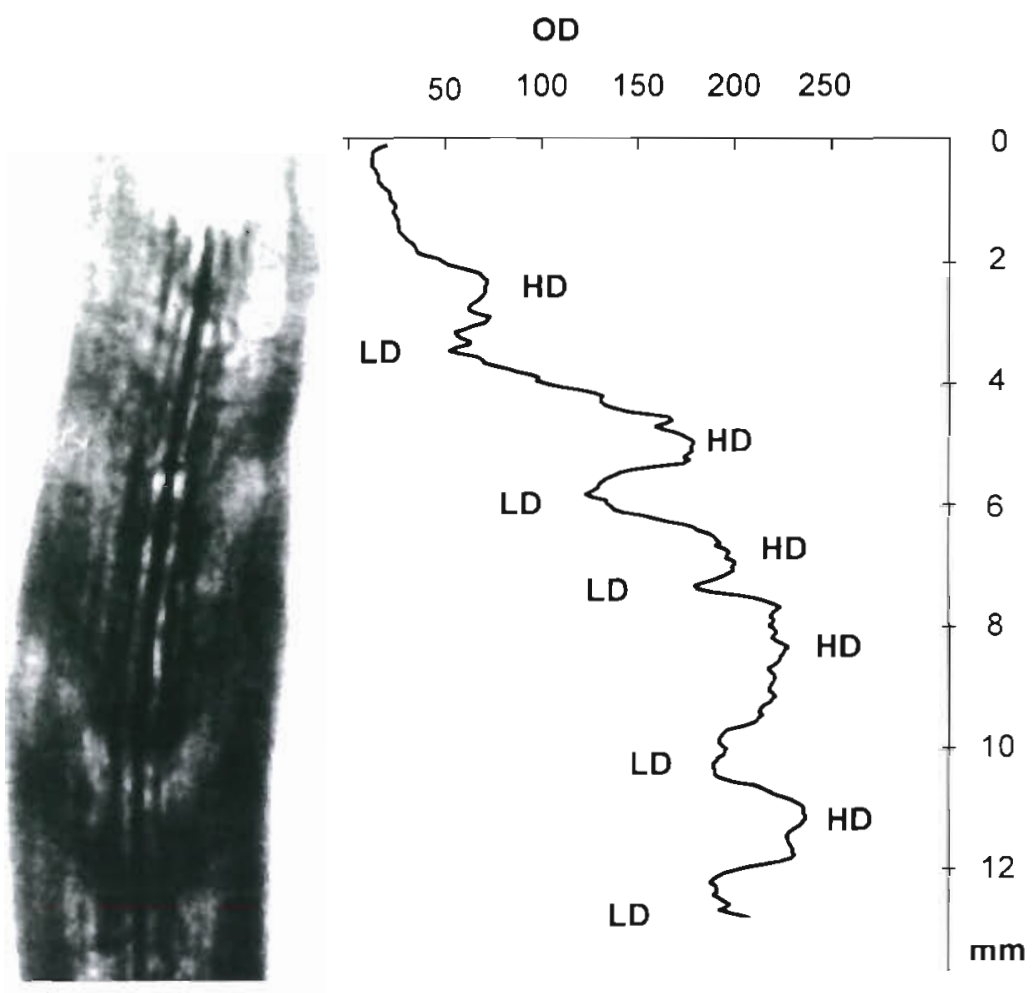

Fig. 2. Cladocora caespitosa. Left: Positive X-ray image of a corallite with dark bands or high density zones (HD) and white bands or low density zones (LD). Right: Resulting image-analysis plot with mean optical density (OD) versus corallite length $(\mathrm{mm})$
The LD band developed in summer (July) and was complete in November. In most instances (see examples shown in Figs. 2 \& 3), both linear growth and density of skeletal deposition were greater during winter months compared to the summer months. No differences were shown in the timing of band deposition between shallow and deeper sites.

\section{Corallite growth}

Annual growth was measured between HD peaks starting from the last completely formed HD band at the apex of each corallite, which corresponded to the year 1993. Subsequent distances between HD bands were measured using a computer measurement procedure. For each colony the annual mean growth rates were thus computed, rang-

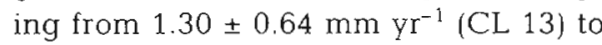
$4.03 \pm 1.42 \mathrm{~mm} \mathrm{yr}^{-1}(\mathrm{PBm} 8)$ (Table 2). Significant differences were found between colonies ( 1 -way Model Il ANOVA, $p<0.01$ ). The computation of variance components showed that differences paliform lobes, or pali, at the centre of the calyx; both septa and pali have spikes on their distal margins (Fig. 3). Dissepimental layers were evident and regularly spaced along the growth axis. In the inner part of the corallite, the fusion of spikes, septa and pali produces the columella, presenting alternate zones with thick and less thick trabecular matrices along the growth axis. On X-radiographs, these zones corresponded to HD and LD bands (Figs. $2 \& 3$ ).

\section{Timing of band deposition}

Identification of the density of the uppermost band on $X$-ray negatives of corallites sampled on different dates showed that Cladocora caespitosa deposits 2 bands $\mathrm{yr}^{-1}$. This coral deposits the HD band during the winter season both in shallow and in deep (>10 m) water (Table 1, Fig. 4). In November, more than $50 \%$ of corallites had started dense band deposition as a ring at the top of the septa; by March, the HD band was fully developed.

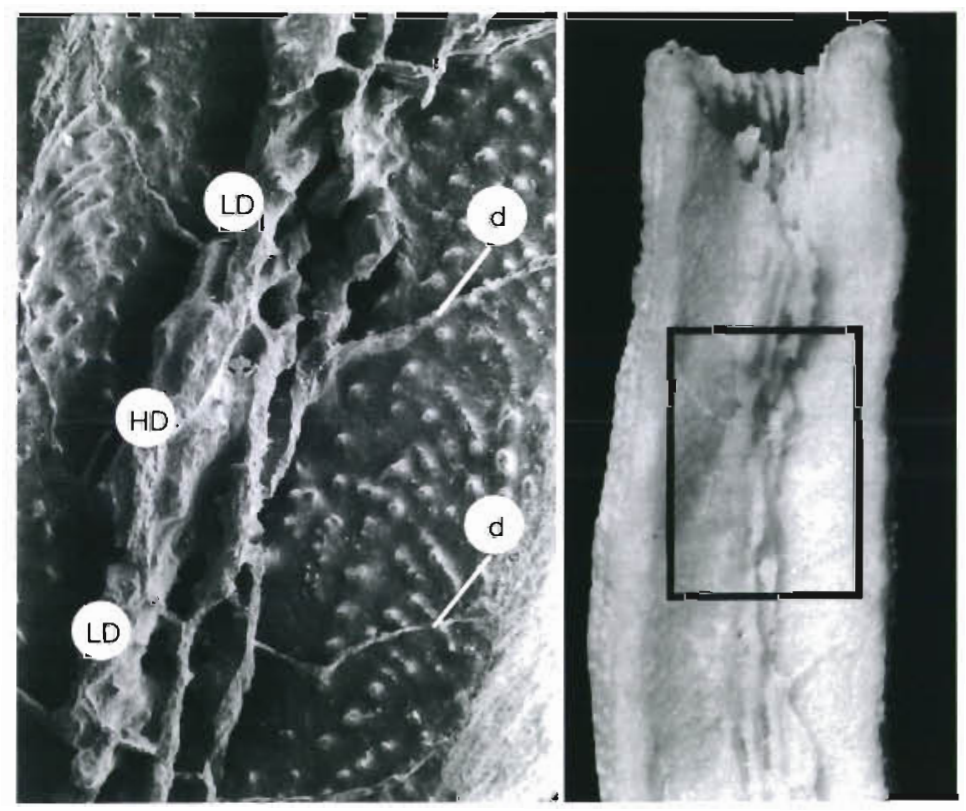

Fig. 3. Cladocora caespitosa. Right: Ground section of the same corallite as in Fig. 2. Left: scanning electron photomicrograph $(\times 30)$ of the rectangular zone shown. The photomicrograph shows dissepiments (d). low density bands (LD), and a high density band (HD) with pali and spines fused together 
Table 1 Cladocora caespitosa. Results of outermost band observation. Percent number of corallites ( \pm confidence limit $95 \%$ ) ending with a high (HD) or low (LD) density band, in shallow or deep $(>10 \mathrm{~m})$ waters. Values in parentheses are actual numbers of corallites. No deep samples were available for November. Data show that most corallites end with a fully developed HD band in March, and with a LD band in July; November represents an intermediate situation

\begin{tabular}{|lccc|}
\hline & November & March & July \\
\hline HD shallow & $51.8 \pm 5.9$ & $71.1 \pm 4.1$ & $17.2 \pm 6.9$ \\
& $(141)$ & $(342)$ & $(20)$ \\
LD shallow & $48.2 \pm 3.0$ & $28.9 \pm 2.07$ & $82.8 \pm 5.2$ \\
& $(131)$ & $(139)$ & $(96)$ \\
HD deep & - & $71.4 \pm 9.7$ & $14.3 \pm 8.2$ \\
& & $(60)$ & $(10)$ \\
LD deep & - & $28.6 \pm 4.9$ & $85.7 \pm 4.2$ \\
& & $(24)$ & $(60)$ \\
& & &
\end{tabular}

within colonies accounted for the largest part of the variability $(62 \%)$.

The differences within each colony might be due to variability in growth among individual corallites or years. This was investigated by a 2 -way Model II ANOVA applied for the period 1989 to 1993. Differences between corallites were highly significant in the colonies BO $(p<0.001), P B n 13(p=0.001)$ and MN 13 $(\mathrm{p}=0.001)$, and significant in the colonies $\mathrm{PBm} 5$ $(p=0.019), \operatorname{PBm} 6(p=0.027), M N 5(p=0.022)$ and MN $18(\mathrm{p}=0.039)$. Differences between years were found only in the colonies PBm $2(p=0.001)$ and CL 20 $(p=0.012)$.

Differences in growth between colonies were tested for 1993 with a 1-way Model II ANOVA and Tukey's
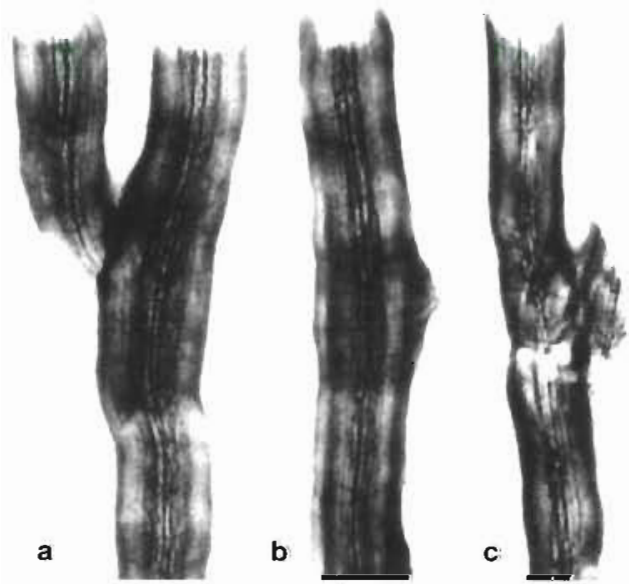

Fig. 4. Cladocora caespitosa. Positive contact prints of X-ray images of apices of corallites collected in different months, all in shallow waters (see Table 2 for sample names): (a) November (PBn13); (b) March (PBm8); (c) July (MN19). Terminal dark (= high density) banding is apparent in November and fully developed in March
Table 2. Cladocora caespitosa. Size (d: maximal diameter; $h$ : maximal height of colonies), mean annual growth rates and standard deviation (SD) of the colonies ( $\mathrm{BO}$ : corallites from Bonassola bank; CL: colonies from Cala Grande; PBm and PBn: colonies collected at Punta Bianca in March and November, respectively; $M N$ : colonies from Capo di Montenero). Differences between means are significant (1-way Model II ANOVA, $\mathrm{p}<0.01$; see 'Results: Corallite growth' for further explanation)

\begin{tabular}{|lrrrrr|}
\hline Sample & d & h & Mean & SD & Years $(\mathrm{n})$ \\
\hline BO & - & - & 2.58 & 0.96 & 63 \\
CL 7 & 11 & 15 & 2.15 & 0.60 & 13 \\
CL 13 & 8 & 3 & 1.30 & 0.64 & 37 \\
CL 18 & 12 & 7 & 1.63 & 0.50 & 12 \\
CL 20 & 12 & 7 & 1.62 & 0.90 & 40 \\
PBm 1 & 20 & 8 & 2.74 & 0.93 & 18 \\
PBm 2 & 15 & 12 & 2.90 & 1.05 & 10 \\
PBm 3 & 12 & 8 & 3.18 & 1.20 & 8 \\
PBm 4 & 12 & 9 & 4.00 & 1.56 & 9 \\
PBm 5 & 12 & 8 & 2.38 & 1.37 & 14 \\
PBm 6 & 20 & 14 & 3.20 & 1.21 & 11 \\
PBm 8 & 24 & 13 & 4.03 & 1.42 & 21 \\
PBn1 & 15 & 7 & 1.79 & 1.09 & 17 \\
PBn 3 & 8 & 5 & 3.60 & 1.04 & 8 \\
PBn 7 & 12 & 12 & 3.54 & 1.28 & 11 \\
PBn 13 & 17 & 15 & 3.31 & 1.25 & 14 \\
PBn 16 & 8 & 9 & 1.78 & 1.24 & 26 \\
PBn 17 & 17 & 9 & 1.88 & 1.38 & 27 \\
MN 1 & 10 & 7 & 1.75 & 0.49 & 10 \\
MN 5 & - & - & 3.60 & 1.33 & 11 \\
MN 11 & - & - & 3.10 & 1.28 & 6 \\
MN 13 & - & - & 3.11 & 0.94 & 13 \\
MN 18 & 7 & 4 & 2.76 & 0.84 & 5 \\
MN 19 & - & - & 3.33 & 1.22 & 9 \\
& & & & & \\
\hline
\end{tabular}

HSD multiple comparison procedure. The matrix of pairwise comparison probabilities showed that colonies could be divided into 5 different groups (Fig. 5). The first group (a in Fig. 5) included 2 slow-growing (1.36 and $1.63 \mathrm{~mm} \mathrm{yr}^{-1}$ ) colonies coming from $20 \mathrm{~m}$ depth; the second group (b) included all the remaining deep $(>10 \mathrm{~m})$ colonies and 3 shallow ones (MN 1, PBn 1, PBn 16) with mean corallite growth between 1.58 and $2.19 \mathrm{~mm} \mathrm{yr}^{-1}$. The third (c) and fourth (d) groups included shallow colonies with corallite growth between 2.55 and $3.23 \mathrm{~mm} \mathrm{yr}^{-1}$, and between 3.30 and $3.90 \mathrm{~mm} \mathrm{yr}^{-1}$, respectively. Finally, the fifth group (e) included the 2 fast-growing colonies (4.29 and $4.42 \mathrm{~mm} \mathrm{yr}^{-1}$ ). This grouping pattern did not appear site-related, since colonies from different sampling stations were intermixed in the 5 clusters. Deep colonies tended to grow less than most of the shallow ones, but the results above suggest that the depth-related difference is not significant, since 3 shallow-water colonies were grouped with deep ones.

Different growth rates and colony morphology were compared plotting the Is-index of Riegl (1995) versus mean growth rates. Comparisons did not show any correlation $(\mathrm{R}=0.263, \mathrm{p}=0.277)$. 


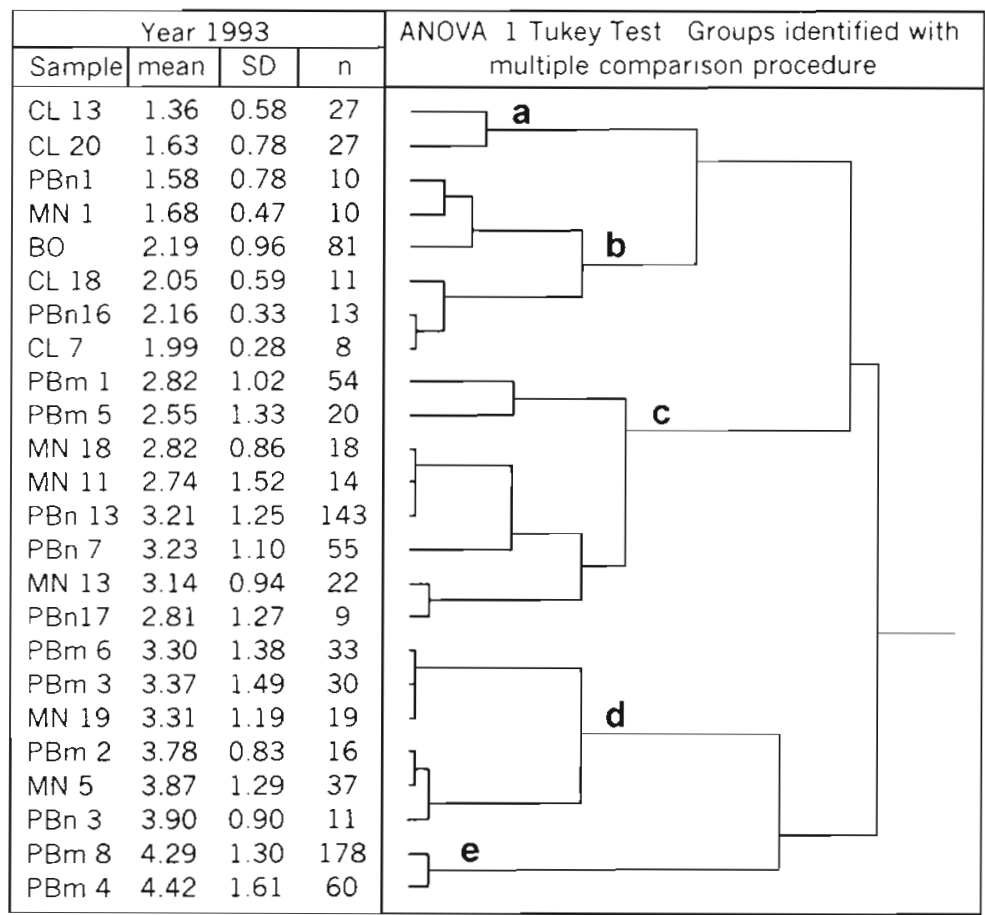

Fig. 5. Cladocora caespitosa. Mean growth rates of colonies in 1993 (SD: standard deviation; $n$ : number of corallites) and groups resulting from 1-way Model II ANOVA and Tukey's HSD multiple comparison test. The dendrogram derives from the matrix of pairwise comparison probabilities using Euclidean distance and complete linkage. Bold letters indicate significant groupings $(\mathrm{p}>0.05)$

\section{DISCUSSION}

\section{Corallite structure}

Our observations suggest that Cladocora caespitosa conforms to a growth model involving 2 processes, as already observed in Porites (Barnes \& Lough 1993, and references therein): (1) lengthening of the calyx wall and (2) internal fusion of skeletal elements.

The first process principally concerns septa and corallite walls. It seems to follow a very regular pattern, as suggested by the relatively constant distance observed between successive dissepimental layers. At no stage did any corallite show a dissepiment near the apex of the calyx. This suggests that the formation of a new dissepiment is started only when the calyx has reached a sufficient height to provide the polyp with the same volume. The above process is consistent with (1) the phaceloid form that allows a continuous development of corallites without restriction of the surface to volume ratio, a potential cause of variation in thickness of the tissue layer in massive corals (Barnes \& Lough 1992); (2) the unlimited life of the polyp; and (3) the direct relationship between corallite diameter and polyp biomass (Schiller 1993a).
The second process (fusion of skeletal elements) is clearly observed in the columella structure and is determined by continuous linear growth during which septa fuse deep in the axis. During the winter season (November to March) the greater density of skeletal deposition influences the architecture and thickness of the columella, with spikes and lobes more closely assembled and fused in HD bands than in LD bands, a process also observed in many tropical corals (Barnes \& Devereux 1988, Barnes \& Lough 1993). In the West Atlantic species Montastrea annularis, HD banding was seen as primarily due to thickening of exothecal elements by Dodge et al. (1992). This cannot be the case for Cladocora caespitosa, however, due to its phaceloid form.

\section{Timing of band deposition}

The banding pattern of the temperate coral Cladocora caespitosa is consistent with Highsmith's (1979) model for 'high latitude' hermatypic species, with the deposition of a denser band in winter and a less dense band during spring to summer. In particular, the deposition pattern of C. caespitosa at latitude $44^{\circ} \mathrm{N}$ resembles that of Porites at $29^{\circ} \mathrm{N}$ in the Red Sea (Klein \& Loya 1991) and that of hermatypic corals near Bermuda $\left(32^{\circ} \mathrm{N}\right.$ ) (Dodge \& Thomson 1974), where the HD band deposition coincides with the period of lowest water temperature.

We found no differences in banding pattern between shallow and deep colonies despite clearly different temperature regimes (Fig. 6). This suggests that density banding in C. caespitosa cannot be interpreted as a temperature effect alone. Schiller (1993b) found that the photosynthetic efficiency of symbiotic zooxanthellae within $C$. caespitosa depends not only on water temperature but also on radiation intensity. This dependence also regulates the rate of carbon utilised for the skeleton.

The deposition in Cladocora caespitosa of a denser band in winter and a less dense band in summer is consistent with Schiller's (1993b) findings on the variable translocation rate of zooxanthella products to the polyp, decreasing from $70 \%$ in winter to $40 \%$ in summer. Differing photosynthetic efficiency of the zooxanthellae in deeper colonies, however, cannot explain the similarity in timing of band deposition since Schiller (1993b) showed that zooxanthella densities and chlorophyll content did not differ from shallow to deep sites. 


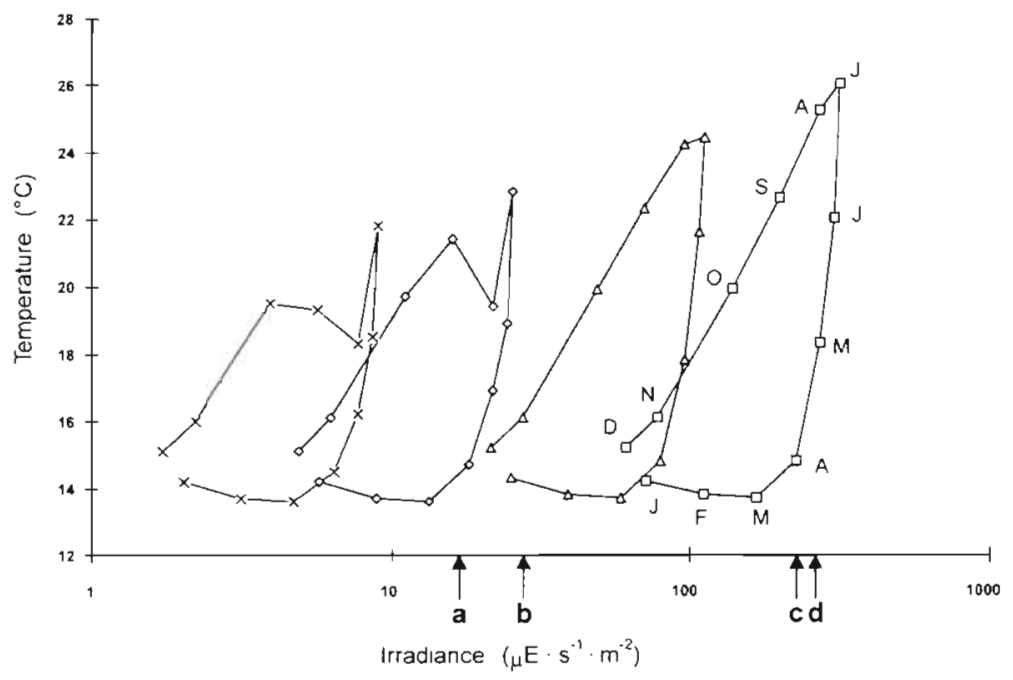

Fig. 6. Monthly temperature-PAR irradiance annual diagrams for the Ligurian Sea at $3(0), 10(\Delta), 20(0)$ and $27 \mathrm{~m}(x)$ depth. Arrows along the $x$-dxis indicate the zooxanthella compensation $(I C)$ and the photosynthesis inhibition $\left(P_{i}\right)$ irradiance levels, according to Schiller $(1993 \mathrm{~b}): \mathrm{a}=I \mathrm{C}$ at $17^{\circ} \mathrm{C}$ seawater temperature; $\mathrm{b}=I \mathrm{C}$ at $21^{\circ} \mathrm{C} ; \mathrm{C}=P i$ at $15^{\circ} \mathrm{C} ; \mathrm{d}=P i$ at $21^{\circ} \mathrm{C}$. Photosynthesis of Cladocora caespitosa at $3 \mathrm{~m}$ depth is likely to be inhibited from April to August. Deeper than $20 \mathrm{~m}$, colonies live at irradiance values below compensation level all year around

In the Ligurian Sea, PAR irradiance levels were optimal for photosynthesis in shallow waters, but below $20 \mathrm{~m}$ depth they were never higher than $26 \mu \mathrm{E} \mathrm{s}^{-1} \mathrm{~m}^{-2}$ (Fig. 6), a value below the zooxanthella compensation irradiance level measured by Schiller (1993b). From May to August, the irradiance could exceed 230 to $250 \mu \mathrm{E} \mathrm{s} \mathrm{m}^{-1}$ in shallow waters, values above which Schiller (1993b) recorded photosynthesis inhibition.

The fact that the deep colonies grow at low irradiance levels throughout the year confirms the importance of 'dark calcification' in zooxanthellate corals (Marshall 1996). It also suggests that growth processes in Cladocora caespitosa are not only related to autotrophy, as hypothesised by Schiller (1993b), but more likely to a combination of autotrophy and heterotrophy, as also observed in the temperate coral Oculina arbuscula (Miller 1995). The relative importance of the 2 contrasting feeding modes in corals has been subject to lengthy debate (Goreau et al. 1971), and differences may exist according to individual species (Risk et al. 1994). Among heterotrophic mechanisms, mucus nets are used by many corals either as a primary or accessory way of feeding (Sorokin 1993, Schlichter \& Brendelberger 1998). Mucus production in C. caespitosa is extremely high. Since the species often lives in turbid environments (Peirano et al. 1998), this mucus production might essentially be a cleaning mechanism (Telesnicki \& Goldberg 1995), but Herndl \& Velimirov (1986) observed that the mucus released by $C$. caespitosa is rutritionally rich. Whether it is utilised as a food source, however, is still to be verified. Another aspect needing further investigation is the role of zooxanthellae in deeper colonies: they might primarily act in recycling nutrients rather than directly participating in the food balance.

\section{Corallite growth}

The rectilinear continuous growth of corallites in Cladocora caespitosa facilitates the measurement of the annual growth rate by avoiding problems related to the 3-dimensional development of corallites of tropical coral species, with massive growth forms.

C. caespitosa growth rates $(1.3$ to $4.3 \mathrm{~mm}$ $\mathrm{yr}^{-1}$ ) in Liguria are similar to those measured with the alizarin method $(2.9$ to $5.2 \mathrm{~mm} \mathrm{yr}^{-1}$ ) on colonies in the Adriatic Sea (Schiller 1993a). The growth rates measured in the Adriatic are within the range of the Ligurian data, despite the lower winter and summer temperatures (from $8.9^{\circ} \mathrm{C}$ in January to $19-21^{\circ} \mathrm{C}$ in August and September) and the greater exposure to storm events at Schiller's (1993a) Adriatic site.

Acknowledgements. We thank F. Spairani and S. Sgorbini for their support in field and laboratory work, G. Calzetta and the staff of the Sarzana Hospital for X-radiographs and S. Furia for her help with image processing. E. Schiano (La Spezia) provided advice on irradiance measures, H. Zibrowius (Marseille), M. Pichon (Perpignan) and M. Le Tissier (Newcastle-upon-Tyne) critically read the manuscript. Suggestions by anonymous referees significantly improved the manuscript.

\section{LITERATURE CITED}

Aguirre J, Jiménez AP (1998) Fossil analogues of present-day Cladocora caespitosa coral banks: sedimentary setting, dwelling community, and taphonomy (Late Pliocene, $W$ Mediterranean). Coral Reefs 17:203-213

Barnes DJ, Devereux MJ (1988) Variation in skeletal architecture associated with density banding in the hard coral Porites. J Exp Mar Biol Ecol 121:37-54

Barnes DJ, Lough JM (1989) The nature of skeletal density banding in scleractinian corals: fine banding and seasonal pattern. J Exp Mar Biol Ecol 126:119-134

Barnes DJ, Lough JM (1992) Systematic variations in the depth of the skeleton occupied by coral tissue in massive colonies of Porites from the Great Barrier Reef. J Exp Mar Biol Ecol 159:113-128

Barnes DJ, Lough JM (1993) On the nature and causes of density banding in massive coral skeletons. J Exp Mar Biol Ecol 167:91-108

Barnes DJ, Taylor RB (1993) On corallites apparent in X-radiographs of skeletal slices of Porites. J Exp Mar Biol Ecol 173:123-131 
Bernasconi MP, Corselli C, Carobene L (1997) A bank of the scleractinian coral Cladocora caespitosa in the Pleistocene of the Crati valley (Calabria, southern Italy): growth versus environmental conditions. Boll Soc Paleontol Ital 36(1-2):53-61

Brown B, LeTissier M, Howard LS, Charuchinda M, Jackson JA (1986) Asynchronous deposition of dense skeletal bands in Porites Iutea. Mar Biol 93:83-89

Buddemeier RW, Maragos JE, Knutson DW (1974) Radiographic studies of reef coral exoskeletons: rates and patterns of coral growth. J Exp Mar Biol Ecol 14:179-200

Charuchinda $M$, Chansang $H$ (1985) Skeleton extension and banding formation of Porites lutea of fringing reefs along the south and west coasts of Phuket Island (Thailand). In: Gabrié $C$ et al. (eds) Proc 5th Int Coral Reef Congr Vol 6. Antenne Museum - EPHE, Moorea, French Polynesia, p 83-87

Della Croce N, Covazzi A, Bonomi A (1992) Valori di trasparenza nei mari Ligure e 'Tirreno. In: Albertelli A, Cattaneo-Vietti R, Piccazzo $M$ (eds) Atti X Congr. Associazione Italiana di Oceanologia e Limnologia, Genova, p 125-133

Dodge RE, Thomson J (1974) The natural radiochemical and growth records in contemporary hermatypic coral from the Atlantic and the Caribbean. Earth Planet Sci Lett 23 $313-322$

Dodge RE, Szmant AM, Garcia R, Swart PK, Forester A, Leder JJ (1992) Skeletal structural basis of density banding in the reef coral Montastrea annularis. In: Richmond RH (ed) Proc 7th Int Coral Reef Symp. Vol 1. University of Guam, Mangilao, p 186-195

Goreau TF, Goreau NI, Yonge CM (1971) Reef corals: autotrophs or heterotrophs? Biol Bull (Woods Hole) 141:247-260

Herndl GJ, Velimirov B (1986) Microheterotrophic utilization of mucus released by the Mediterranean coral Cladocora cespitosa. Mar Biol 90:363-369

Highsmith RC (1979) Coral growth rates and environmental control of density banding. J Exp Mar Biol Ecol 37:105-125

Hudson HJ, Hanson KJ, Halley RB, Kindinger JL (1994) Environmental implications of growth rates changes in Montastrea annularis: Biscayne National Park, Florida Bull Mar Sci 54(3):647-669

Innamorati M (1990) Misurazione dell'irradianza. Nova Thalassia 11:11-67

Klein R, Loya Y (1991) Skeletal growth and density patterns of two Porites corals from the Gulf of Eilat, Red Sea. Mar Ecol Prog Ser 77:253-259

Klein R, Pätzold J, Wefer G, Loya Y (1992) Seasonal variations in the stable isotopic composition and the skeletal density pattern of the coral Porites lobata (Gulf of Eilat, Red Sea) Mar Biol 112:259-263

Klein R, Pätzold J, Wefer G, Loya Y (1993) Depth-related timing of density band formation in Porites spp. corals from the Red Sea inferred from X-ray chronology and stable isotope composition. Mar Ecol Prog Ser 97:99-104

Knutson DW, Buddemeier RW, Smith SV (1972) Coral chronometers: seasonal growth bands in reef coral. Science 177: $270-272$

Kühlmann DHH (1996) Preliminary report on Holocene submarine accumulation of Cladocora caespitosa (L. 1767) in the Mediterranean. Göttinger Arb Geol Paläont Sb 2: $65-69$

Kühlmann DHH, Chintiroglou H, Koutsoubas D, Koukouras A (1991) Korallenriffe in Mittelmeer? Naturwiss Rundsch $44(8): 316$

Laborel J (1961) Sur un cas particulier de concrétionnement animal. Concrétionnement à Cladocora caespitosa (L.) dans le Golfe de Talante. Rapp P-V Réun Comm Int Explor Sci Mer 16(2):429-432
Le Tissier MD'AA, Clayton B, Brown BE, Spencer DP (1994) Skeletal correlates of coral density banding and an evaluation of radiography as used in sclerochronology. Mar Ecol Prog Ser 110:29-44

Lough JM, Barnes DJ (1990) Possible relationships between environmental variables and skeletal density in a coral colony from the Great Barrier Reef. J Exp Mar Biol Ecol 134:221-241

Lough JM, Barnes DJ (1997) Several centuries of variation in skeletal extension, density and calcification in massive Porites colonies from the Great Barrier Reef: a proxy for seawater temperature and a background of variability against which to identify unnatural change. I Exp Mar Biol Ecol 211:29-67

Marshall AT (1996) Calcification in hermatypic and ahermatypic corals. Science 271:637-639

McCree KJ (1972) Test of current definitions of photosynthetically active radiation against leaf photosynthesis data. Agric Meteorol 13:349-357

Miller MW (1995) Growth of a temperate coral: effects of temperature, light, depth, and heterotrophy. Mar Ecol Prog Ser 122:217-225

Morri C, Peirano A, Bianchi CN, Sassarini M (1994) Present-day bioconstructions of the hard coral, Cladocora caespitosa (L.) (Anthozoa, Scleractinia), in the eastern Ligurian Sea (NW Mediterranean). Biol Mar Medit 1(1): $371-372$

Oliver JK, Chalker BE, Dunlap WC (1983) Bathymetric adaptations of reef-building corals at Davies Reef, Great Barrier Reef, Australia. I. Long-term growth responses of Acropora formosa (Dana 1846). J Exp Mar Biol Ecol 73:11-35

Osservatorio Meteorologico di Genova (1985) Riassunto 1985. Istituto Geofisico e Geodetico, Università di Genova, p 1-4

Peirano A, Morri C, Mastronuzzi G, Bianchi CN (1998) The coral Cladocora caespitosa (Anthozoa, Scleractinia) as a bioherm builder in the Mediterranean Sea. Mem Descr Carta Geol d'It 52(1994):59-74

Picco P (1990) Climatological atlas of the western Mediterranean. ENEA, Centro Ricerche Ambiente Marino, La Spezia

Riegl B (1995) Effects of sand deposition on scleractinian and alcyonacean corals. Mar Biol 121:517-526

Risk MJ, Sammarco PW, Schwarcz HP (1994) Cross-continental shelf trend in $\delta^{13} \mathrm{C}$ in coral on the Great Barrier Reef. Mar Ecol Prog Ser 106:121-130

Schiller C (1993a) Ecology of the symbiotic coral Cladocora caespitosa (L.) (Faviidae, Scleractinia) in the Bay of Piran (Adriatic Sea): I. Distribution and biometry. PSZN I: Mar Ecol 14(3):205-219

Schiller C (1993b) Ecology of the symbiotic coral Cladocora caespitosa (L.) (Faviidae, Scleractinia) in the Bay of Piran (Adriatic Sea): II. Energy budget. PSZN I: Mar Ecol 14(3): 221-238

Schlichter D, Brendelberger H (1998) Plasticity of the scleractinian body plan: functional morphology and trophic specialization of Mycedium elephantotus (Pallas, 1766). Facies 39:227-242

Sorokin YI (1993) Coral reef ecology. Ecological Studies 102, Springer Verlag, Berlin

Telesnicki GJ, Goldberg WM (1995) Effects of turbidity on the photosynthesis and respiration of two South Florida reef coral species. Bull Mar Sci 57 (2):527-539

Veron JEN (1993) Corals of Australia and the Indo-Pacific. University of Hawaii Press, Honolulu

Zibrowius H (1980) Les Scléractiniaires de la Méditerranée et de l'Atlantique nord-oriental. Mém Inst Océanogr (Monaco) 11:1-284 